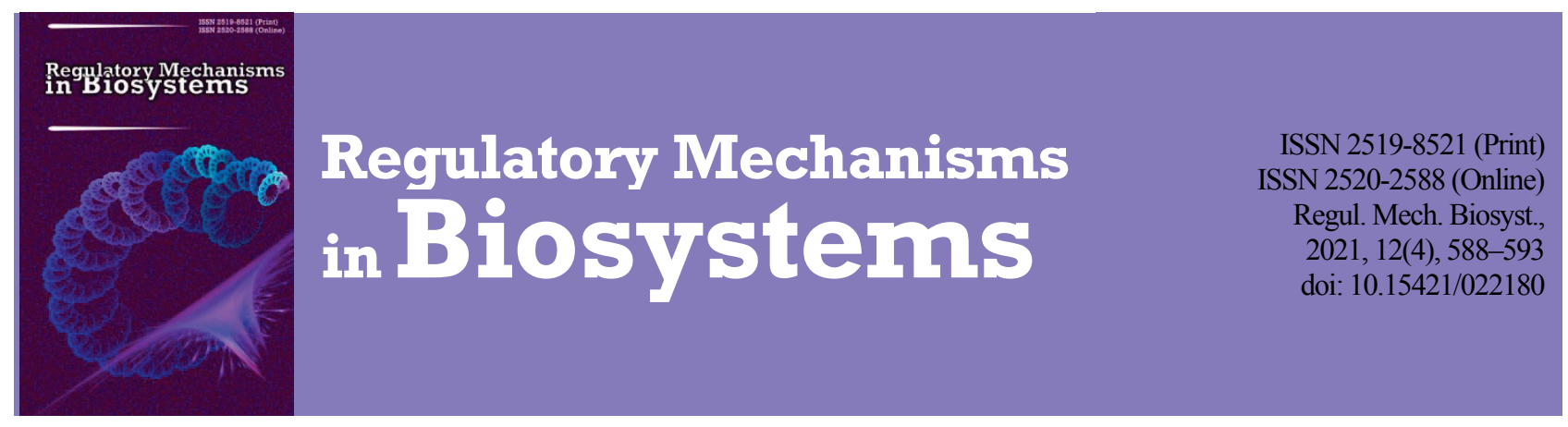

\title{
Morphological and physiological-biochemical variability of spore-forming bacteria isolated from the agrocoenosis of winter wheat
}

\author{
A. Honchar*, O. Tonkha* , N. Patyka*, Y. Lykholat**, T. Patyka* \\ *National University of Life and Environmental Science of Ukraine, Kyiv, Ukraine \\ **Oles Honchar Dnipro National University, Dnipro, Ukraine
}

Article info

Received 19.10.2021

Received in revised form 10.11 .2021

Accepted 14.11.202

Honchar, A., Tonkha, O., Patyka, N., Lykholat, Y., \& Patyka, T. (2021). Morphological and physiological-biochemical variability of spore-forming bacteria isolated from the agrocoenosis of winter wheat. Regulatory Mechanisms in Biosystems, 12(4), 588-593. doi:10.15421/022180

From an agrocoenosis of winter wheat (Triticum aestivum L.; phylloplane and rhizosphere of the root system; typical chernozem, soil column measuring up to $40 \mathrm{~cm}$ ), using the classical microbiological methods, we had isolated soil bacteria and characterized them according to the morphological features as representatives of Gram-positive and spore-forming bacteria of Bacillus sp. genus. In the earing-swelling

National University

of Life and Environmental

Science of Ukraine,

Heroyiv Oboronyst., 13 ,

Kyiv, 03041, Ukraine

Tel.: +38-096-956-58-19

E-mail:

byasya40@gmail.com

Oles Honchar Dnipro

National University.

Gagarin av., 72 ,

Dnipro, 49010, Ukraine.

Tel.: +38-050-229-20-48.

E-mail:

lykholat2006@ukr.net phase of grain, the screening studies found non-pigmented forms of colonies of bacterial isolates, 19 of which were classified to colonialmorphological diversity of R-type with the diameter of 7 to $13 \mathrm{~mm}$. The analysis of physiological condition of cells of populations of soil isolates revealed technologic specificity according to parameters of spore formation in different conditions and incubation time (up to 48 $72 \mathrm{~h}$ ). We observed $90.0 \%$ of free spores in axenic cultures as early as after $72 \mathrm{~h}$ of cultivation and no more than $10.0 \%$ of prospores in the studied monoisolates with stable morphologic traits. Isolates $\mathrm{H} 10$ and $\mathrm{H} 45$ demonstrated the ability to grow in higher cultivation temperatures $\left(+37 \ldots+40^{\circ} \mathrm{C}\right)$. According to environmental $\mathrm{pH}$, isolates were able to grow in $\mathrm{pH}$ ranging 4.5-8.0. Differential diagnostic testing revealed that as the source of carbon, with formation of acid, soil isolates used arabinose, xylose, mannitol, glucose, galactose, fructose, maltose, sorbitol, glycerin, dextrin, starch, rhamnose and dulcite (with development of alkaline). There was observed active use of mineral forms of nitrogen: ammonium salt and nitrates, aminoacids and proteins. The isolates hydrolyzed casein, gelatin, starch, and litmus was being reduced in the young during growth in milk with litmus. They also exerted catalase activity and were oxidase-positive. Biochemical testing using API test system determined that the studied isolated bacteria differed by a range of fermentation carbohydrates, reduction of nitrates. In the conditions of submerged fermentation, isolates $\mathrm{H} 38$ and $\mathrm{H} 40$ grew in heightened temperature ranges of cultivation $\left(40{ }^{\circ} \mathrm{C}\right)$ for $48 \mathrm{~h}$ (according to fact of spore development). Therefore, according to the key morphologic and biochemical traits, strains H3, H10, H13, $\mathrm{H} 36, \mathrm{H} 38, \mathrm{H} 40, \mathrm{H} 43, \mathrm{H} 45$ were similar to such of reference strain B. subtilis 8A, and were identified to Bacillus sp., species B. subtilis.

Keywords: soil bacteria; screening; spores; strain; morphotypes; biochemical reaction; identification.

\section{Introduction}

Aerobic spore-forming bacteria are common in the nature and are important constituents of soil microbiocoenosis. They are highly biologically active, particularly in synthesizing biologically active metabolites, which are different in nature and action mechanism, and also enzymes, polysaccharide complexes with adjuvant, immune-modulating properties, aminoacids, vitamins and other compounds (Agarwal et al., 2017; Patyka et al., 2019, 2020; Soni et al., 2021). Scientific interest to spore-forming bacteria, particularly those of Bacillus genus, is related to variety of their ecological niches (from various forms of parasitism to commensalism, mutualism), specific structure (ability to develop endospores) and ability to synthesize a broad spectrum of active primary and secondary metabolites (Kaspar et al., 2019; Prakash et al., 2021). Representatives of Bacillus (B. subtilis, $B$. megaterium, B. atrophaeus, B. licheniformis, B. amiloliquefaciens, B. pumilus, $B$. mojavensis and others) are the most sensible and dynamic components of microbial groups of soil, especially in the conditions of anthropogenic pressure and various stress factors (Andreyuk et al., 2001; Saxena et al., 2019). Many strains of this group are primary producers of various antibiotic substances and bacteriocines (antimicrobial peptides or proteins, which are considered alternative to traditional antibiotics against causative agents of plant diseases, as well as growth stimulators for agricultural crops). The ability of soil spore bacteria to level out phytopathoge- nic organisms may be due to high rates at which they occupy ecological niches (for example in rhizosphere), and the ability to biosynthesize antibiotic substances and other antifungal metabolites (Caulier et al., 2019; Kiroiants et al., 2021). Multifaceted orientation of metabolic processes, genetic and biochemical variability, resistance to lytic and herbaceous enzymes justified the active use of soil bacteria in various spheres of agriculture and medicine (Safronova et al., 2012; Orlova et al., 2015; Irkitova et al., 2018; Volkogon et al., 2018; Patyka et al., 2019).

Using soil microorganisms for agroecosystems is considered an effective for correcting rhizosphere microbiome, improving growth and functional parameters of plants' development and increasing their productivity (Gadzalo et al., 2015; Volkogon et al., 2018). Promising directions are believed to be the study of polyfunctional activity of soil bacteria associated with the rhizosphere of cultivated grasses, search of target primary producers among them (biologically active complexes) and study of their potential properties, specificity (Lambers et al., 2009; Rastogi et al., 2011; Gadzalo et al., 2019). Because of the specifics of the rhizosphere bacteria, there may be developed conditions for support of efficiency in managing plant-microbial systems with participation of natural biological mechanisms. Search of new highly effective strains of spore-forming bacteria from agrocoenoses, obtaining various combinations of microbial preparations on their basis for cultivating plants, and soil science are fundamental for the modern biotechnologic industry. The objective of this study was 
determining morphologic and physiologic-biochemical properties of studied isolates of spore-developing bacteria selected from agrocoenosis of winter wheat (Triticum aestivum L.).

\section{Materials and methods}

The objects of our study were soil microorganisms (new isolates), which were isolated from rhizosphere samples of winter wheat varieties
(Separate Division of the National University of Bioresources and Environment of Ukraine Educational-Research Farm Agronomic Experimental Station): in the boot and earing-grain swelling stages, we analyzed 20 varieties (Muza bilotserkivs'ka, Namysto, Schedrivka Kyivs'ka, Myronivs'ka Slava, Analoh, Harantiia Odes'ka, Trudivnytsia Myronivs'ka, MIP Dniprianka, MIP Valensiia, Prozoryi, Polis'ka 90, Zdoba Kyivs'ka, Tradytsiia Odes'ka, Manera Odes'ka, Lehenda Bilotserkivs'ka, Lainer, Lisova Pisnia, Veteran, Nyva Odes'ka, Shliakhetna), Table 1.

Table 1

New isolates and sources of isolation of spore bacteria of Bacillus genus, which were used for microbiological studies (2019-2020)

\begin{tabular}{|c|c|c|c|}
\hline $\begin{array}{l}\text { Number of axenic } \\
\text { cultures (isolates) }\end{array}$ & Varieties of winter wheat & Source of isolate & Notes: symptoms of diseases of plants \\
\hline $\mathrm{H} 3$ & Namysto & rhizosphere of the root system & brown spots on leaves in the lower part of stem \\
\hline H5 & Schedrivka Kyiivs'ka & phylloplane (surface) of the root system & lower part of leaves has rusty-brown plumage \\
\hline H9, H9a & Harantiia Odes'ka & common chernozem, column down to $40 \mathrm{~cm}$ & brown plumage on axes of leaves \\
\hline $\mathrm{H} 10$ & Trudivnytsia Myronivska & $\begin{array}{l}\text { common chernozem, column down to } 40 \mathrm{~cm} \\
\text { rhizosphere of the root system }\end{array}$ & brown plumage in the lower part of stem \\
\hline H11 & MIP Dniprianka & & brown plumage on leaf \\
\hline H13 & MIP Valensiia & rhizosphere of the root system & brown-rusty plumage on leaf \\
\hline H16, H17 & Polis ka 90 & rhizosphere of the root system & brown and light-brown spots on lower leaves with signs of chlorosis \\
\hline H19 & Zdoba Kyiivs'ka & $\begin{array}{l}\text { common chernozem, column down to } 40 \mathrm{~cm} \text { rhizosphere } \\
\text { of the root system }\end{array}$ & rusty-brown longitudinal spots on leaves in the lower parts \\
\hline $\mathrm{H} 20$ & Tradytsia Odes'ka & phylloplane (surface) of the root system & rusty-brown leaves \\
\hline $\mathrm{H} 21, \mathrm{H} 22$ & Manera Odes'ka & rhizosphere of the root system & brown spot on leaf, brown axis of leaf \\
\hline $\mathrm{P} 23, \mathrm{H} 24$ & Lehenda Bilotserkivs'ka & $\begin{array}{l}\text { common chernozem, column down to } 40 \mathrm{~cm} \\
\text { rhizosphere of the root system }\end{array}$ & rusty-brown leaves \\
\hline $\mathrm{H} 26$ & Lainer & rhizosphere of the root system & light-brown spot on light-green leaves \\
\hline $\mathrm{H} 28$ & Lisova Pisnia & rhizosphere of the root system & dark-brown spot on leaf \\
\hline $\mathrm{H} 33, \mathrm{H} 34, \mathrm{H} 34 \mathrm{a}$ & Polis'ka 90 & rhizosphere of the root system & brown leaves in the lower part of the plant \\
\hline H36 & Schedrivka Kyiivska & $\begin{array}{l}\text { common chernozem, column down to } 40 \mathrm{~cm} \\
\text { rhizosphere of the root system }\end{array}$ & brown spot on the lower leaf \\
\hline $\mathrm{H} 38$ & Lehenda Bilotserkivs'ka & phylloplane (surface) of the root system & brown leaves \\
\hline $\mathrm{H} 40, \mathrm{H} 41, \mathrm{H} 41^{1}, \mathrm{H} 42$ & Analoh & rhizosphere of the root system & dark plumage on the stem, brown plumage on the leaf \\
\hline $\mathrm{H} 44$ & Zdoba Kyiivska & common chernozem, column down to $40 \mathrm{~cm}$ & brown spots on leaf \\
\hline $\mathrm{H} 45$ & Lainer & phylloplane (surface) of the root system & brown leaves \\
\hline H51 & Valensiia & rhizosphere of the root system & brown spot on the flag leaf \\
\hline
\end{tabular}

In the study, we used reference strain B. subtilis 8A (RCAM 00876), which was isolated from grain of winter wheat of Nota variety, deposited on 14.11.2011 at a well-known collection of beneficial microorganisms for agricultural purposes of the All-Russian Scientific Research Institute of Agricultural Microbiology. The scheme of screening of soil microorganisms is in the experimental block:

- obtaining the enrichment culture (suspension of axenic cultures of spore microorganisms, cultural liquid, population of colonies) (Zvyagintsev, 1991; Yamborko, 2018);

- microbiological inoculation, surface-growing or submerged cultivation of bacteria were carried out using the generally accepted microbiological and biotechnological methods (Tepper, 1993; Patyka, 2018) - meatpeptone agar, MPA; potato agar, PA, glucose-peptone agar, GPA in modification of Zviahintsev, LB medium; the temperature of cultivation was $35^{\circ} \mathrm{C}$, and the time of cultivation was $72 \mathrm{~h}$.

Isolation of pure (axenic) cultures from grown colonies of microorganisms, microscopy of live or fixated preparations (fuchsine-stained), hematocymeter, light microscopy (equipment - Sigeta MB-130 (40×, $100 \times)$, China; digital non-ocular system of cell visualization EVOS FL Imaging System, Thermo Fisher Scientific, USA).

We determined morphotypes of bacterial spore-forming isolates and their main physiologic and biochemical properties (Lengeler et al., 1999; Radchenko, 2012; Belyaev, 2016; Patyka, 2018).

Analysis of bacterial isolates of Bacillus genus was carried out using direct microscopic methods. Spore-forming bacteria were isolated by deep inoculation of suspensions (subsequent dilutions to $10^{-7}$ and $10^{-8}$ ) into 1.0 $1.5 \%$ agarous growth media LB, MPA, KA. The ability of microorganisms to develop spores were checked by heating the cellular suspensions on water bathe in the temperature of $100{ }^{\circ} \mathrm{C}$ for 10,20 and 30 minutes.

After three days of incubation of the cultures of microorganisms in the thermostat in the temperature of $28-32{ }^{\circ} \mathrm{C}$, the colonies that were similar in morphology of bacillus forms had been selected and re-inoculated using classical microbiological technique of streak inoculation (Zvyagintsev, 1991) and Streak Plate Method (https://vlab.amrita.edu). Tech-

nological and physiological conditions of axenic culture were controlled on different growth media in the conditions of submerged fermentation (0.5-1.0-liter glass Erlenmeyer flasks) on biotechnological thermoregulating platform with orbital movement of the operating zone equaling $220 \mathrm{rpm}$ and $28-30^{\circ} \mathrm{C}$ temperature range for bacterial growth for no less than $36 \mathrm{~h}$. Changes in morphological traits of spore-developing culture were determined using microscopy.

Physical-biochemical studies were carried out using a complex of differentiation-diagnostic tests, namely by acetyl methyl carbinol (AMC), hydrolysis of starch, proteolysis on meat-peptone gelatin (MPG), reduction of nitrates to nitrites, ability of developing hydrolytic enzymes, assimilation of organic sources of carbon according to methodological recommendations (Zvyagintsev, 1991; Reva et al., 2001; Belyaev, 2016). Oxidase and catalase activities were determined using the described methods (Kovács, 1956; Egorov, 1976; Lui et al., 1986). The enrichment cultures were used in order to study morphological, physiological and biochemical properties of pure cultures of soil bacteria. In the study, we employed API test systems for spore-forming microorganisms of Bacillus genus (20A, 50CHB). Stripes of API were inoculated in bacterial suspension and incubated in $28^{\circ} \mathrm{C}$ for $24 \mathrm{~h}$. The results were analyzed according to the manufacturer's recommendations and using the data base included in the software APILAB Plus (BioMérieux, France).

\section{Results}

As a result of the studies, we isolated 29 isolates of bacteria, the colonies of which were light gray or creamy in color. From the rhizosphere of winter wheat in the earing phase, we isolated 17 isolates of bacteria, in the phase of earing-swelling of grain - 12 (Fig. 1). The isolated bacterial cultures are characterized by R-type of colonies: scabrous, wrinkled, mat, with wavy margin (Table 2). According to the results of the primary screening, from the rhizosphere of winter wheat, we took 19 isolates of the bacteria, the colonies of which were yellow, 15 - gray and 2 - creamy or gray-white. 


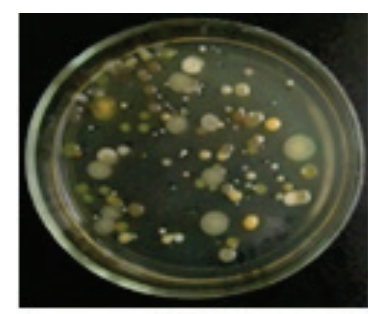

a

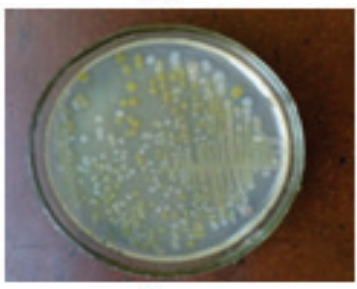

d

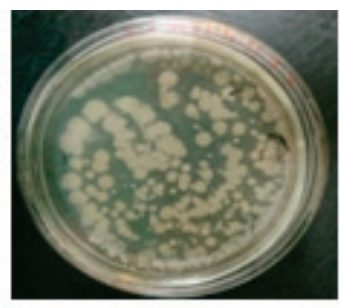

b

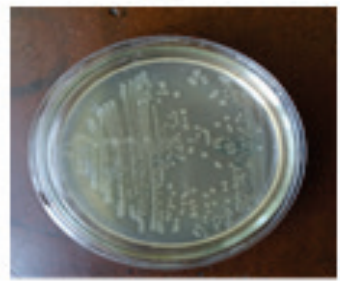

e

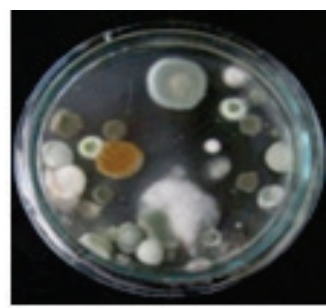

C

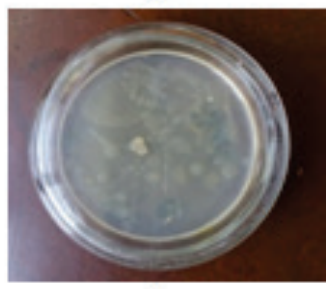

f

Fig. 1. Morphological-colonial variety of spore-forming microorganisms $(a, b, c, d, e)$ and micromycetes $(c, f)$ isolated from the rhizosphere of winter wheat

In the phase of earing-swelling of grain of winter wheat, we isolated the highest number of non-pigmented isolates of spore-forming bacteria. The studies of morphological and physiological-biochemical characteristics of the bacterial isolates according to gave the following results: in the cycle of the development, bacteria developed rod-shaped type of cells; in general, those cells were in the shape of regular rod with rounded ends. The size of cells varied $0.9-1.4 \times 2.5-3.6 \mu \mathrm{m}$. Cells were mobile, located as concentrations or singular chains of different length in the smears. They were characterized as Gram-positive, non-capsuled. We observed the development of spores that had central position in the cells according to the bacillary type of location. In the cultural fluid, the cells were mobile, moving using peritrichous flagella.

Table 2

Test of morphological types of bacterial isolates

\begin{tabular}{cl}
\hline $\begin{array}{c}\text { Bacterial } \\
\text { isolates }\end{array}$ & \multicolumn{1}{c}{ Characteristics of colonies of isolated bacteria } \\
\hline 1 & Bright creamy (yellow-pigmented), slightly swell, viscous (Chm-1) \\
2 & Gray, singular colony, semi-transparent, wavy margin \\
3 & Non-pigmented, grayish white, slightly swell, viscous \\
4 & Creamy, slightly swell, viscous \\
5 & Gray, semi-transparent, with slightly swell center; gray (singular) (Chm-3a) \\
6 & Gray, semi-transparent, wavy margin \\
7 & Gray, singular, semi-transparent, wavy margin; yellow-pigmented colo- \\
& nies were found \\
8 & Mixture of yellow and gray colonies. For the study, there was selected \\
9 & gray colony of bacteria \\
10 & Gray, semi-transparent, wavy margin \\
11 & Gray-milky, creamy, non-transparent \\
13 & Gray, singular, semi-transparent, flat, wavy margin \\
14 & Gray, singular, semi-transparent, flat, wavy margin \\
15 & Gray, singular, semi-transparent, flat, wavy margin \\
16 & Gray (en masse), semi-transparent, flat, wavy margin \\
17 & Gray (en masse), semi-transparent, flat, wavy margin \\
18 & Gray, semi-transparent, flat, wavy margin \\
19 & Gray, semi-transparent, flat, wavy margins \\
\hline
\end{tabular}

We determined variety of morphological-colonial types of isolates (gray to light creamy with different sizes and shapes of margin). The colonies on the surface of universal growth media emerged 17-22 h following the inoculation to agarous surface. The colonies were graywhite, non-transparent, flat, of irregular or rounded shapes, with finescabrous surface, wavy margin, viscous in consistency. In the temperature of $+28^{\circ} \mathrm{C}$, most new isolates on the nutritive agar formed gray colonies, paste-like consistencies with irregular and torn margins. The diameter of the colonies equaled up to 10-14 mm. In general, during the tests, isolates displayed growth in the temperature range of $+18 \ldots+37^{\circ} \mathrm{C}$, and two isolates $(\mathrm{H} 10, \mathrm{H} 45)$ were able to grow in the range of $+37 \ldots+40{ }^{\circ} \mathrm{C}$. In the temperatures over $+40{ }^{\circ} \mathrm{C}$ and less than $+15{ }^{\circ} \mathrm{C}$, the growth of spore-developing bacteria significantly slowed. In relation to environmen- tal $\mathrm{pH}$, the isolates demonstrated ability to develop in $\mathrm{pH}$ measuring 4.5 8.0 (Table 3). No development of bacteria was observed in more alkaline conditions ( $\mathrm{pH} 9.0-10.0)$. Optimum value of environmental $\mathrm{pH}$ equaled 7.1-7.5.

Table 3

Growth of bacterial isolates in various ranges of temperatures and $\mathrm{pH}$

\begin{tabular}{lcccccccccc}
\hline Iso- & \multicolumn{7}{c}{ Temperature, ${ }^{\circ} \mathrm{C}$} & \multicolumn{7}{c}{$\mathrm{pH}$} \\
\cline { 2 - 9 } lates & $+18 \ldots . .25$ & $+26 \ldots .32$ & $+33 \ldots .35$ & +37 & +40 & $4.5-5.0$ & $5.5-6.0$ & $6.5-7.0$ & $7.5-8.0$ \\
\hline $\mathrm{H} 3$ & + & + & + & - & - & + & + & + & + \\
$\mathrm{H} 10$ & + & + & + & + & + & + & + & + & + \\
$\mathrm{H} 11$ & + & + & + & + & - & + & + & + & + \\
$\mathrm{H} 13$ & + & + & + & + & - & + & + & + & + \\
$\mathrm{H} 17$ & + & + & + & + & - & + & + & + & + \\
$\mathrm{H} 26$ & + & + & + & - & - & + & + & + & - \\
$\mathrm{H} 36$ & + & + & + & - & - & + & + & + & + \\
$\mathrm{H} 28$ & + & + & + & + & - & + & + & + & + \\
$\mathrm{H} 33$ & + & + & + & + & - & + & + & + & + \\
$\mathrm{H} 34 \mathrm{a}$ & + & + & + & + & - & + & + & + & - \\
$\mathrm{H} 38$ & + & + & + & + & - & + & + & + & + \\
$\mathrm{H} 40$ & + & + & + & + & - & + & + & + & + \\
$\mathrm{H} 41$ & + & + & + & + & - & + & + & + & + \\
$\mathrm{H} 41$ & + & + & + & + & - & + & + & + & - \\
$\mathrm{H} 43$ & + & + & + & + & - & + & + & + & + \\
$\mathrm{H} 45$ & + & + & + & + & + & + & + & + & + \\
$\mathrm{H} 51$ & + & + & + & - & - & + & + & + & - \\
\hline
\end{tabular}

Specifics of growth and development of soil isolates were reflected in long lag phases (up to $48 \mathrm{~h}$ ) and long post-stationary stage of the development without rapid decrease in the number of vital cells. In two days of cultivation in MPB, they have grown as evenly turbid media, producing small sediment. On the surfaces of liquid media, the strains formed a thin film (veil), the column of media was transparent under the film, having no pigmentation, and the color of growth medium did not change.

The ranges of the carbon nutrition and enzymatic activity of isolates $\mathrm{H} 38$, H40 were identical to such of typical strain B. subtilis 8A (RCAM 00876). As the source of carbon, the isolates used arabinose, xylose, mannitol, glucose, galactose, fructose, maltose, sorbitol, glycerin, dextrin, starch, rhamnose, producing acid, and dulcite (with development of alkaline) (Table 4).

As a result of the conducted studies, we determined that the following mineral forms of nitrogen were used: salt ammonium and nitrates of aminoacids and proteins. Isolates $\mathrm{H} 3, \mathrm{H} 10, \mathrm{H} 13, \mathrm{H} 36, \mathrm{H} 38, \mathrm{H} 40, \mathrm{H} 43, \mathrm{H} 45$ hydrolized casein, gelatin, and also starch and litmus milk (with loss of color). The experimental isolates were catalase-positive.

The studied isolates did not develop indole, and did reduce nitrates to nitrites. During the cultivation on diagnostic media, we observed that the growing bacteria were generating acetoin (acetyl methyl carbinol, AMC) on the growth media with peptone and glucose. Strains isolated from the phytoplane of the root system of winter wheat exerted the ability to breakdown starch, and biochemical abilities similar to other strains. 
At the same time, the hydrolisys zone was 2.8 to $4.0 \mathrm{~mm}$. Strains had proteolytic activity that manifested in liquefaction of gelatin and peptonization of casein milk.

\section{Table 4}

Physiological-biochemical characteristics of Gram-positive spore-forming isolates from phylosphere and rhizosphere of the root system of winter wheat and typical chernozem

\begin{tabular}{|c|c|c|c|}
\hline \multirow[b]{2}{*}{ Tests } & \multicolumn{2}{|c|}{ Bacterial isolates } & \multirow[b]{2}{*}{$\begin{array}{l}\text { Reference } \\
\text { strain } \\
\text { B. subtilis } \\
\text { 8A (RCAM } \\
\text { 00876) }\end{array}$} \\
\hline & $\begin{array}{l}\text { H3, H10, } \\
\text { H13, H36, } \\
\text { H38, H40, } \\
\text { H43, H45 }\end{array}$ & $\begin{array}{c}\text { H11, H17, H26, } \\
\text { H28, H33, } \\
\text { H34a, H41, } \\
\text { H41 }{ }^{1}, \mathrm{H} 51\end{array}$ & \\
\hline Reduction of nitrates to nitrites & + & + & + \\
\hline $\begin{array}{l}\text { Development: } \\
\text { hydrogen sulfide } \\
\text { indole }\end{array}$ & $\begin{array}{l}+ \\
-\end{array}$ & $\begin{array}{l}+ \\
-\end{array}$ & $\begin{array}{l}+ \\
-\end{array}$ \\
\hline Hydrolysis - gelatin & + & + & + \\
\hline casein & + & + & + \\
\hline $\begin{array}{l}\text { Hydrolysis - starch } \\
\text { growth on litmus milk }\end{array}$ & + & + & + \\
\hline Catalase activity & + & + & + \\
\hline Urease activity & - & - & - \\
\hline Oxidase activity & + & - & + \\
\hline Use (fermentation): & & & \\
\hline glucoses & A & A & A \\
\hline arabinoses & A & A & A \\
\hline fructoses & A & A & A \\
\hline sacharoses & A & A & A \\
\hline xyloses & A & A & A \\
\hline galactoses & A & A & + \\
\hline mannoses & A & A & + \\
\hline raffinoses & A & - & + \\
\hline salycil & + & + & + \\
\hline dulcitol & + & + & + \\
\hline maltoses & + & + & + \\
\hline rhamnoses & + & + & + \\
\hline sorbitol & A & $\mathrm{A}$ & A \\
\hline mannitol & A & A & A \\
\hline inositol & A & A & A \\
\hline Voges-Proskauer test & + & + & + \\
\hline
\end{tabular}

Note: "+"- presence of trait, “-”- absence of trait, "A"-acid.
Biochemical tests using API test system revealed that the studied isolates of bacteria differed by the spectrum of fermented carbohydrates, reduction of nitrates and oxidase activity (Table 5).

We determined that isolates of H38 and H40 in the conditions of submerged fermentation were able to grow in heightened temperature ranges of cultivation $\left(40^{\circ} \mathrm{C}\right)$, and the optimum technological period was no less than $48 \mathrm{~h}$ (according to the fact of spore development). The results of determining phenotype traits allowed us to consider the studied isolates belonging to the Bacillus sp. genus. Furthermore, based on physiologicbiochemical properties, the isolated strains may be identified to species B. subtilis.

\section{Discussion}

Systematics (taxonomic positions) of different species of spore-developing bacteria is actively developing and changes as a result of expansion and accumulation of new data. To obtain the necessary data, the entire diversity and specifics of the external and internal structures of the microorganisms are studied, their physiological, biochemical properties, and also processes these organisms cause in their environments (Smirnov, 2001; Patyka et al., 2018). The basis for identifying the taxonomic position, as earlier, comprises the following: morphological properties of cells (shape, sizes, mutual location, spore-development, Gram-staining, etc.); cultural, biochemical, antigen characteristics, and also sensitivity to different antimicrobial activities and the extent of genetic similarity with representatives of other taxa (homology of nucleic acids and ability to exchange genetic information). Thus, to identify the species of a tested soil or rhizosphere isolate, there should be employed the following scientific-method principles and approaches: study of morphological traits (types) of isolates; characteristics of the specifics of metabolism, ways to obtain energy and other physiological properties.

Also, morphological-physiological traits for identification of bacteria should include such parameters as pathogenity in relation to other organisms; influence of the environment on vitality of studied object (microorganism) and stability of bioagent properties; pattern of changes in the growth medium where intense growth is taking place, development and accumulation of biomass, etc (Berendsen et al., 2015; Ferone et al., 2020).

Table 5

Biochemical testing of isolates on API stripes for spore-forming microorganisms

\begin{tabular}{|c|c|c|c|c|c|c|c|c|}
\hline Well & Substrate & Reaction/enzyme & $\begin{array}{l}\text { Isolate } \\
\text { H5 }\end{array}$ & $\begin{array}{c}\text { Isolate } \\
\text { H16 }\end{array}$ & $\begin{array}{c}\text { Isolate } \\
\text { H34 }\end{array}$ & $\begin{array}{c}\text { Isolate } \\
\mathrm{H} 38\end{array}$ & $\begin{array}{c}\text { Isolate } \\
\mathrm{H} 40\end{array}$ & $\begin{array}{c}\text { B. subtilis 8A } \\
\text { (RCAM 00876) }\end{array}$ \\
\hline $\mathrm{NO}_{3}$ & Potassium nitrate & reduction of nitrates & - & - & - & + & + & + \\
\hline TRP & L- tryptophan & production of indole & - & - & - & - & - & - \\
\hline GLU & D-glucose & fermentation & + & + & + & + & + & + \\
\hline $\mathrm{ADH}$ & L-arginine & arginine dihydrolase & - & - & + & + & - & - \\
\hline URE & Urea & urease & - & - & - & - & - & - \\
\hline ESC & trisubstituted iron citrate & hydrolysis ( $\beta$-glucosidase) & - & + & - & + & + & + \\
\hline GEL & Gelatin & gelatinase & + & + & - & + & + & + \\
\hline PNPG & 2-nitrophenyl- $\beta$-D-galactoside & $\beta$-galactosidase & + & + & + & - & + & + \\
\hline GLU & D-glucose & assimilation & + & + & + & + & + & + \\
\hline ARA & L- arabinose & assimilation & + & + & + & + & + & + \\
\hline MNE & D-mannose & assimilation & + & + & + & + & + & + \\
\hline MAN & D- mannitol & assimilation & + & + & + & + & + & + \\
\hline NAG & $\mathrm{N}$-acetyl-glucosamine & assimilation & + & + & + & + & + & + \\
\hline MAL & D-maltose & assimilation & + & + & - & + & + & + \\
\hline GNT & Potassium gluconate & assimilation & + & + & + & + & + & + \\
\hline CAP & Caproic acid & assimilation & - & + & - & - & - & - \\
\hline ADI & Adipic acid & assimilation & - & - & - & - & - & - \\
\hline MLT & Malic acid & assimilation & + & + & - & + & + & - \\
\hline CIT & Trisubstituted sodium citrate & assimilation & + & + & + & + & + & + \\
\hline PAC & Phenylacetic acid & assimilation & + & - & - & + & + & + \\
\hline Oxidase & & & - & - & - & + & + & + \\
\hline
\end{tabular}

Note: "-"-trait is negative; "+"- trait is positive.

Complex in vitro studies of microorganisms are significant not only for the nomenclature and taxonomy, but also for assessing the role of microorganism in particular environmental conditions, and also its scientificpractical significance. For the purposes of further studies, there should be made a data base comprising information on genotypes of bacterial cultu- res that are promising for application in agromicrobiology, biotechnology, and also polymorphism of genes that cause extreme biological, technological activities should be analyzed. It should be noted that polymorphism of microbiome of spore-forming bacteria is a platform for discussions. Parasitism or symbiotic interaction "microorganism - environment" is ac- 
companied by development of a significant biochemical differentiation expressed in narrower trophic specialization and dependence on many growth actors (vitamins, aminoacids, etc.). Cells of bacteria of the Bacillus genus are distinct by the abilities and strategies of colonizing growth media of various densities. At the same time, emergence of morphological variants in the process of dissociation (specific type of variability, breakdown of homogenous bacterial population into variants that vary in genetic, physiological-biochemical, morphological properties) increases the heterogeneity of some populations of microorganism in mobility and ability to chemo-response. The literature data indicates that impairment in the processes of spore development among bacteria may be related with change in their physiological and biochemical properties, insufficient influx of nutrients into environment (Boyko et al., 2017).

Microbiological analyses of the selected isolates revealed that morphological-colonial diversity of spore-forming microorganisms and micromycetes is the commonest, which is explained by sufficient conditions of moisture for wheat plants in the vegetation period (starting from spring vegetation), and also variety-related specifics of a particular field plot. The general pool of saprotrophic microorganisms of the rhizosphere may change toward ecoplastic bacilli. Extension of scientific knowledge of biological characteristics and variability of soil microorganisms adapted to the conditions of winter wheat is becoming more relevant. It is important to select producer strains with high colonization ability, stability and integration of components of plant-microbial systems in the conditions of modern agroproduction, technical pressure and stresses, and also carry out the selections considering the efficiency of biocontrol functions of rhizosphere of bacteria (antifungal activity, etc).

According to the main types of colonies, the following R-types were found: gray, flat profile, fine-grained structure, non-transparent with finescabrous surface, up to $10 \mathrm{~mm}$ in diameter (type 1); creamy-colored, wavy margin, flat profile, scabrous, up to $7 \mathrm{~mm}$ in diameter (type 2); grayish white, having rhizoid or wavy margins, scabrous, viscous, up to $13 \mathrm{~mm}$ in diameter (type 3). Analysis of promising strains according to physiological condition of cells of populations of soil microorganisms in the aspect of properties of spore development during cultivation in liquid nutritive media revealed that growth intensity of certain strains in different conditions and identical time period (after 49-72 h) has certain peculiarities. Free spores (up to $90.0 \%$ were observed in axenic cultures as early as after $72 \mathrm{~h}$ of cultivation of the prospore (up to $10.0 \%$ ) according to all determined monoisolates of morphotypes $1-3$, which is coherent with the results obtained by Crickmore (2000) and Boyko et al. (2017). In the process of selective breeding and subsequent generations, it is important to select promising strains of rhizosphere soil, which would combine practically valuable properties, technological requirements for and stability of the morphological traits. Physiological growth parameters (temperature regime, environmental $\mathrm{pH}$ ), in which the bacteria can actively reproduce are important (Reva et al., 2001; Patyka et al., 2018). The broad demonstrated growth range of the studied isolates indicates their high adaptive abilities and vitality in various temperatures, $\mathrm{pH}$. The results we obtained are important for further selection of promising spore-forming strains for horticulture and soil sciences.

As we saw in the conducted block of experimental studies, according to morphological, physiological-biochemical characteristics, the isolated strains (H3, H10, H13, H36, H38, H40, H43, H45) were similar to such of reference strain $B$. subtilis $8 \mathrm{~A}$. Variety of growth conditions of the studied bacteria allows us to presume that they have potentially beneficial physiological-biochemical properties, including thermostability and stability in broad range of $\mathrm{pH}$ values. To confirm the identification of species of representatives of microbial group of rhizosphere of soil of winter wheat, these strains shall be further identified using molecular-biological method (comparative analysis of nucleotide series of 16S RNA gene of bacteria of Bacillus genus).

\section{Conclusions}

Variety of morphological and biochemical peculiarities of species of spore-forming bacteria of the Bacillus genus determines their differences in the spectrum of their actions and manifestations of biological properties in the natural environment. Comparison of the results that we obtained in our study with the results described in other scientific articles may suggest that morphological and physiological-biochemical characteristics of isolates of bacteria isolated from agrocoenosis of winter wheat extends the knowledge from the fundamental perspective. The most technological monoisolates were three cultural-morphological types (R-types) with high growth rate, spore development, and also stability during passages and changes in the cultivation conditions. The isolates were identified according to the phenotype and physiological-biochemical properties, their correspondence to reference strain Bacillus subtilis 8A. Based on the obtained results, we may presume that because of their biological properties, strains of natural types H3, H10, H13, H36, H38, H40, H43, H45 may be promising for the development of effective technologies of the production of microbial preparations, and also integrated study of mechanisms of plantmicrobial interactions (according to type of induced transformations at morphological, cytological, physiological-biochemical, genetic levels in the organism). Experimental data confirm the relevance of broadening the scientific knowledge of biological characteristics of new strains of Bacillus subtilis and search of specific primary producers of metabolites adapted to the conditions of rhizosphere of winter wheat.

The present research was fully self-funded by the authors. No competing interests have been declared.

\section{References}

Agarwal, M., Dheeman, S., Dubey, R. C., Kumar, P., Maheshwari, D. K., \& Bajpai, V. K. (2017). Differential antagonistic responses of Bacillus pumilus MSUA3 against Rhizoctonia solani and Fusarium oxysporum causing fungal diseases in Fagopyrum esculentum Moench. Microbiological Research, 205, 40- 47.

Andreyuk, K. I., Iutinskaya, G. O., Antipchuk, A. F., \& Valagurova, O. V. (2001). Funktsionuvannya mikrobnykh tsenoziv gruntu $\mathrm{v}$ umovakh antropohennoho navantazhenn [Functioning of microbial coenoses of soil in the conditions of anthropogenic loading]. Oberehy, Kyiv (in Ukrainian).

Belyaev, S. A. (2016). Mikrobiologiya [Microbiology]. Lan P, Saint Petersburg (in Russian).

Berendsen, R. L., Pieterse, C. M. J., \& Bakker, P. A. H. M. (2012). The rhizosphere microbiome and plant health. Trends Plant Science, 17, 478 486.

Boyko, M. V., Patyka, N. V., \& Patyka, T. I. (2017). Estimation of productivity Bacillus thuringiensis on different med. Microbiology and Biotechnology, 1, $16-22$.

Caulier, S., Nannan, C., Gillis, A., Licciardi, F., Bragard, C., \& Mahillon, J. (2019). Overview of the antimicrobial compounds produced by members of the Bacillus subtilis group. Frontiers Microbiology, 10, 302.

Crickmore, N. (2000). The diversity of Bacillus thuringiensis $\delta$-endotoxins. In: Charles, J.-F., Delecluse, A., \& Nielsen-Le Roux, C. (Eds.). Entomopathogenic bacteria: From laboratory to field application. Kluwer Academic Publishers, Dordrecht. Pp. 65-79.

Egorov, N. S. (1976). Praktikum po mikrobiologii [Workshop on microbiology]. Publishing House of Moscow University, Moscow (in Russian).

Ferone, M., Gowen, A., Fanning, S., \& Scannell, A. G. M. (2020). Microbial detection and identification methods: Bench top assays to omics approaches. Comprehensive Reviews in Food Science and Food Safety, 19(6), 3106-3129.

Gadzalo, Y. M., Patyka, M. V., Zaryshnyak, A. S., \& Patyka, T. I. (2019). Ahromikrobiolohiya $\mathrm{z}$ osnovamy biotekhnolohiyi [Agromicrobiology with the basics of biotechnology]. Ahrarna Nauka, Kyiv (in Ukrainian).

Gadzalo, Y. M., Patyka, N. V., \& Zarishnyak, A. S. (2015). Agrobiologiya rizosfery rasteniy [Agrobiology of the rhizosphere of plants]. Ahrama Nauka, Kyiv (in Ukrainian).

Irkitova, A. N., Grebenshchikova, A. V., Yatsenko, E. S., Speranskaya, N. Y., \& Matsyura, A. V. (2018). Morphological diversity of Bacillus subtilis. Ukrainian Journal of Ecology, 8(2), 365-370.

Kaspar, F., Neubauer, P., \& Gimpel, M. (2019). Bioactive secondary metabolites from Bacillus subtilis: A comprehensive review. Journal of Natural Products, 82(7), 2038-2053.

Kiroiants, M., Patyka, M., \& Patyka, T. (2021). Otsinka biolohichnoji efektyvnosti perspektyvnykh dominantnykh shtamiv bakterij ryzosfery jachmeniu jaroho [Estimation of the biological efficiency of prospective dominant strains of bacteria in the rhizosphere of spring barley]. Scientific Reports of National University of Life and Environmental Science of Ukraine, 1, 89 (in Ukrainian).

Kovács, N. (1956). Identification of Pseudomonas pyocyanea by the oxidase reaction. Nature (London), 178, 703

Lambers, H., Mougel, C., Jaillard, B., \& Hinsinger, P. (2009). Lant-microbe-soil interactions in the rhizosphere: An evolutionary perspective. Plant and Soil, 321, 83-115. 
Lengeler, J., Drews, G., \& Schlegel, H. (Eds.). (1999). Biology of prokaryotes. Blackwell Science, Oxford.

Lui, J.-K., \& Jurtshuk, P. J. (1986). N,N,N'-N'-tetramethyl-p-phenylenediaminedependent cytochrome oxidase analyses of Bacillus species. International Journal of Systematic Bacteriology, 36(1), 38-46.

Orlova, O. V., Andronov, E. E., Vorobyov, N. I., Patyka, N. V., \& Sviridova, O. V. (2015). Sostav i funktsionirovanije mikrobnogo soobshchestva pri razlozhenii solomy zlakovykh kul'tur $\mathrm{v}$ dernovo-podzolistoj pochve [Composition and functioning of microbial communities in the decomposition of straw cereals in sod podzolic soil]. Sel'skokhozyaistvennaya Biologiya, 50(3), 305-314 (in Russian).

Patyka, N. V., \& Patyka, T. I. (2020). Symbiontni mikrobni uhrupovannia komakh: Funktsionuvannia ta initsiatsija potentsialu entomopatohennoji diji na prykladi Bacillus thuringiensis [Symbiotic microbial communities of insects: Functioning and entomopathogenic action potential initiation on the example of Bacillus thuringiensis]. Mikrobiolohichnyi Zhurnal, 82(1), 62-73 (in Ukrainian).

Patyka, N. V., Bublik, N. A., \& Patyka, T. I. (2015). Rhizosphere trophic chains: Role and stability in soil processes and ecosystems. Journal of Characterization and Development of Novel Materials, 7(3), 413-418.

Patyka, N. V., Tonkha, O. L., Sinchenko, V. N., Honchar, A. N., \& Patyka, T. I. (2019). Osoblyvosti formuvannia strukturovo-funktsional'noho skladu mikrobiomu chornozemu tsilynnoho $\mathrm{v}$ stepu Ukrajiny [Features of the formation of the structural and functional composition of the microbiome of chernozem virgin in the steppe of Ukraine]. Mikrobiolohichnyi Zhurnal, 81(4), 90-106 (in Ukrainian).

Patyka, T. I., \& Patyka, M. V. (2018). Biotekhnolohiya mikrobnoho syntezu [Biotechnology of microbial synthesis]. Nilan Ltd., Vinnytsia (in Ukrainian).

Patyka, T. I., \& Patyka, M. V. (2020). Bacillus thuringiensis spp. israelensis and control of Aedes aegypti invasive mosquitoes species in ecosystems. Mikrobiolohichnyi Zhurnal, 82(5), 88-97.

Prakash, J., \& Arora, N. K. (2021). Novel metabolites from Bacillus safensis and their antifungal property against Alternaria alternata. Antonie Van Leeuwenhoek, 114(8), 1245-1258.

Radchenko, O. S. (2012). Fizioloho-biokhimichni vlastyvosti mikroorhanizmiv ta metody jikh vyznachennia [Physiological and biochemical properties of micro- organisms and methods of their determination]. Agrar Media Group LLC, Kyiv (in Ukrainian).

Rastogi, G., \& Sani, R. K. (2011). Molecular techniques to assess microbial community structure, function, and dynamics in the environment. microbes and microbial technology. In: Ahmad, I., Ahmad, F., \& Pichtel, J. (Eds.). Microbes and microbial technology: Agricultural and environmental applications. Springer, New York. Pp. 29-57.

Reva, O. N., Sorokulova, I. B., \& Smirnov, V. V. (2001). Simplified technique for identification of the aerobic spore-forming bacteria by phenotype. International Journal of Systematic and Evolutionary Microbiology, 51(4), 1361-1371.

Safronova, L. A., Zelena, L. B., Klochko, V. V., \& Reva, O. N. (2012). Does the applicability of Bacillus strains in probiotics rely upon their taxonomy. Canadian Journal of Microbiology, 58(2), 212-219 (in Ukrainian).

Saxena, A. K., Kumar, M., Chakdar, H., Anuroopa, N., \& Bagyaraj D. J. (2019). Bacillus species in soil as a natural resource for plant health and nutrition. Journal of Applied Microbiology, 128(6), 1583-1594.

Soni, R., \& Keharia, H. (2021). Phytostimulation and biocontrol potential of Grampositive endospore-forming Bacillus. Planta, 254(3), 49.

Tepper, E. Z. (1993). Praktikum po mikrobiologii [Workshop on Microbiology]. Kolos, Moscow (in Russian).

Volkogon, V., Pyrig, O., \& Brytan, T. (2018). Directedness of soil-microbiological processes under the influence of organic and mineral fertilizers. Visnyk Ahrarnoji Nauky, 96(6), 5-11.

Yamborko, H. V., Yelyns'ka, N. O., Zinchenko, O. Y., \& Vasyl'yeva, N. Y. (2018). Mikrobiolohija z osnovamy virusolohiji: Metodychni vkazivky do laboratornykh zaniat' dlia studentiv khimichnoho fakul'tetu [Microbiology with the basics of virology: A methodical instructions to the laboratory classes for students of the faculty chemistry]. Odessa National University named after I. I. Mechnikov, Odesa (in Ukrainian).

Zvyagintsev, D. (1991). Metody pochvennoj mikrobiologiji i biokhimiji [Methods of soil microbiology and biochemistry]. Moscow State University Publishing House, Moscow (in Russian). 